\title{
STAN I PRZYSZŁOŚĆ GOSPODARSTW EKOLOGICZNYCH W DROBNOOBSZAROWYM ROLNICTWIE WOJEWÓDZTWA MAŁOPOLSKIEGO
}

\section{INNOVATION IN FRAGMENTED AGRICULTURE ON THE EXAMPLE OF ORGANIC FARMS IN THE MAŁOPOLSKIE VOIVODSHIP}

\author{
Agnieszka GIL \\ Uniwersytet Pedagogiczny im. KEN w Krakowie \\ Instytut Geografii \\ ul. Podchorążych 2, 30-084 Kraków \\ agnieszka.gil@wp.pl
}

\begin{abstract}
Zarys treści: Województwo małopolskie cechuje się silnym rozdrobnieniem rolnictwa, które w bardzo wolnym stopniu zmienia swoją strukturę i modernizuje sposoby produkcji. Duża część najmniejszych gospodarstw rezygnuje z uprawy roli i nie prowadzi chowu zwierząt. Prowadzi to do spadku efektywności sektora rolnego tego regionu i ogranicza wykorzystanie istniejącej siły roboczej, zasobów ziemi rolniczej i zaangażowanego kapitału. Pojawiają się tu jednak działania o innowacyjnym charakterze, polegające na rozwoju wielofunkcyjnego rolnictwa i organizowaniu gospodarstw ekologicznych, agroturystycznych czy też wytwarzających produkty rolne metodami tradycyjnymi (produkty regionalne). W niniejszej pracy skupiono się na działalności gospodarstw ekologicznych, których w Małopolsce jest blisko 2 tys. Stanowiły one w 2012 r. 6,9\% ogółu gospodarstw ekologicznych w kraju. Ich istnienie i szybki rozwój traktować można jako znaczący w skali całego regionu kierunek zmian rolnictwie. W artykule zawarto analizę dynamiki ilościowej tych gospodarstw, scharakteryzowano uwarunkowania ich rozwoju w różnych warunkach środowiska przyrodniczego i społeczno-ekonomicznego Małopolski oraz omówiono główne problemy związane z produkcją, zbytem i przetwórstwem. Starano się też ukazać ich perspektywy jako jeden ze sposobów ożywienia rolnictwa regionu. Praca oparta jest w dużej części na własnych badaniach przeprowadzonych w gospodarstwach ekologicznych. Wykazały one, że przyszłość rolnictwa ekologicznego w województwie małopolskim jest niepewna. Na przeszkodzie ich organizowania stoi przede wszystkim brak kompleksowego podejścia do funkcjonowania gospodarstw od momentu ich powstania, poprzez proces produkcji, aż po organizację sieci dystrybucji. Powinien powstać spójny system ich gospodarowania w gospodarce żywnościowej regionu.
\end{abstract}

Słowa kluczowe: ekologia, gospodarstwa ekologiczne, produkcja ekologiczna, rolnictwo.

\section{Wprowadzenie}

Zarówno w Europie, jak i w Polsce rolnictwo ekologiczne ma już za sobą długi okres funkcjonowania w strukturach gospodarki żywnościowej. Staje się ono znaczącą alternatywą dla rolnictwa przemysłowego w wytwarzaniu „zdrowej żywności” i szansą dla gospodarstw wielu krajów i regionów posiadających korzystne warunki dla uprawy roślin i cho- 
wu zwierząt metodami ekologicznymi. Jego powstanie łączy się najczęściej z inicjatywami podejmowanymi w ramach rozwoju wielofunkcyjnej gospodarki wiejskiej, w ramach której także rolnictwo poszerza działalność o nowe rodzaje produkcji i przetwórstwa płodów rolnych, a także korzystne dla zdrowia człowieka sposoby ich wytwarzania. Polska ma duże możliwości rozwoju rolnictwa ekologicznego, zwłaszcza w regionach o znacznym potencjale przyrodniczym i produkcyjnym związanym z zasobami siły roboczej, tradycjami rolniczymi i dobrym położeniem wobec rynku konsumenckiego. Jednak w ogólnym potencjale wytwórczym polskich gospodarstw udział rolnictwa ekologicznego jest niewielki, a obserwowane w tym zakresie zmiany są powolne. Można stwierdzić, że wzrost liczby rolników produkujących w naszym kraju żywność ekologiczną jest bardziej powiązany z programami wsparcia finansowego pochodzącymi z funduszy Unii Europejskiej niż z osiąganymi efektami produkcyjnymi, gwarantującymi konkurencyjność w stosunku do innych grup gospodarstw. Taka sytuacja dotyczy też województwa małopolskiego, będącego przedmiotem niniejszej analizy, które jeszcze niedawno wyróżniało się na tle kraju znacznym udziałem gospodarstw ekologicznych (w 2006 r. było tu prawie 15\% gospodarstw ekologicznych Polski), lecz dynamika ich rozwoju znacznie osłabła i w 2013 r. udział ten spadł o połowę (do 6,9\%). Wielu rolników podjęło działalność ekologiczną, korzystając ze wsparcia wspomnianych funduszy europejskich, ale spora ich grupa już obecnie lub też w nieodległej przyszłości, kiedy upłynie termin zobowiązań wobec Unii Europejskiej, zamierza zrezygnować z ekologicznych metod produkcji. Wyłania się zatem problem pogłębionych badań nad przyczynami małego, a nawet spadającego zainteresowania rolników takim sposobem wytwarzania żywności oraz analizy funkcjonowania gospodarstw ekologicznych w krajowych i regionalnych ogniwach żywnościowych. Z tego m.in. powodu starano się w niniejszej pracy pokazać główne ograniczenia rozwoju rolnictwa ekologicznego w Małopolsce i określić możliwości wzrostu jego udziału w gospodarce regionu.

W analizie założono, że gospodarstwa rolne Małopolski muszą zdecydowanie lepiej wykorzystywać posiadany potencjał wytwórczy, a w szczególności istniejące duże zasoby siły roboczej, związane z rozdrobnieniem gospodarstw. To rozdrobnienie pozostanie jeszcze przez dłuższy czas dominującą cechą rolnictwa, a związane z nim ograniczenia produkcyjne można w znacznym stopniu złagodzić, upowszechniając ekologiczne metody produkcji. Region może stać się równocześnie znaczącym konsumentem „zdrowej żywności" skierowanej do Krakowa i na zaopatrzenie miejscowych uzdrowisk (Krynica, Muszyna, Piwniczna, Szczawnica, Wysowa) oraz ośrodków turystycznych. W artykule zwrócono także uwagę na rolę rolnictwa ekologicznego jako elementu innowacyjności zmieniającego cechy produkcyjne drobnoobszarowego rolnictwa oraz jego techniczne i organizacyjne sposoby wytwarzania żywności.

Celem opracowania jest rozpoznanie kondycji i perspektyw rozwoju rolnictwa ekologicznego w województwie małopolskim. Źródło danych stanowiły badania ankietowe przeprowadzone od września 2013 do listopada 2014 r. w 100 certyfikowanych gospodarstwach ekologicznych. Przeprowadzono je trzema sposobami: ankietę rozesłano do respondentów drogą elektroniczną, przeprowadzono ankiety telefonicznie oraz prowadzono wywiady bezpośrednio z osobami prowadzącymi gospodarstwa ekologiczne. 


\section{Dynamika gospodarstw ekologicznych w Małopolsce}

W 2013 r. w regionie Małopolski ekologiczne sposoby działalności rolniczej stosowało 1838 gospodarstw, podczas gdy w całym kraju było ich ogółem prawie 26,6 tys. Od 2006 r. ich liczba wzrosła prawie o 500 jednostek (nieco ponad 1/3). Natomiast w tym samym czasie w kraju odnotowano wzrost o ponad 17,7 tys. (z 9,2 tys. do 26,6 tys.), tj. blisko trzykrotny. Największy wzrost zanotowano w trzech województwach: podlaskim, warmińsko-mazurskim i zachodniopomorskim, z 1892 w 2006 r. do 11878 w 2013, a więc ponad sześciokrotny. Jeśli w pierwszym z porównywanych okresów udział wspomnianych województw w ogólnej liczbie gospodarstw ekologicznych wynosił niewiele ponad 20\% i był nieznacznie wyższy niż w samym tylko województwie małopolskim, to w 2013 r. wzrósł on do ponad 50\%. Województwa te nadal powiększają swój "ekologiczny potencjał", bowiem w latach 2012-2013 liczba analizowanych gospodarstw wzrosła o blisko tysiąc, gdy w kilku województwach południowej Polski miał w tym czasie miejsce ich ubytek, a dotyczyło to głównie województwa małopolskiego. Było ono w okresie tych dwóch lat, obok województwa podkarpackiego, miejscem największego regresu rolniczej działalności ekologicznej, bowiem z rejestru wypadło ponad 270 gospodarstw (około 12\% ogółu, gdy w podkarpackim 190, tj. około $10 \%$ ogółu; ryc. 1).

Zmiany liczby gospodarstw ekologicznych w Polsce wymagają szerszego komentarza, a przede wszystkim oceny ich znaczenia w kształtowaniu rynku artykułów produkowanych metodami ekologicznymi. Na początku trzeba stwierdzić, że wysoka dynamika wzrostu ich liczby w trzech wspomnianych województwach dotyczyła głównie sadownictwa i zakładanych na dużych powierzchniach plantacji orzechów włoskich, orzechów laskowych, a także borówki amerykańskiej. Szczególnie charakterystyczne dla tych zmian były sady z orzechami włoskimi. B. Głębocki (2014) wyjaśnia, że powstawały one głównie na terenach, gdzie istniały spore zasoby ziemi powstałe po likwidacji PGR (głównie w województwie zachodniopomorskim), a najważniejszym czynnikiem tak wysokiej dynamiki były dopłaty pochodzące z funduszy europejskich. Stwierdza on również, że sady często zakładały osoby niemające związku z rolnictwem. W raporcie sporządzonym dla Sejmu RP ustalono, że w 2103 r. nie dawały one żadnej produkcji, ale na ich utrzymanie wydano ponad $50 \mathrm{mln}$ zł (Szymona 2013). Drugim kierunkiem wzrostu segmentu gospodarki ekologicznej na terenie wymienionych trzech województw było organizowanie na powierzchniach trawiastych, które nie spełniały kryteriów charakteryzujących użytki zielone, ekologicznego chowu zwierząt „,kolczykowatych”. Natomiast trzecim kierunkiem była uprawa zbóż. W sumie wymienione działania w sferze gospodarstw ekologicznych nie dawały istotnego przyrostu produkcji ekologicznej. Inaczej było w regionach o dużym rozdrobnieniu rolnictwa obejmujacych województwa „dawnej Polski” - małopolskie, podkarpackie, świętokrzyskie czy lubelskie. Tutaj rolnictwo ekologiczne koncentruje się na produkcji warzyw, owoców miękkich, jabłek, mleka, jaj czy mięsa wołowego uzyskiwanego w drodze ekstensywnego wypasu (Guzik i Leśnicki 2003). 


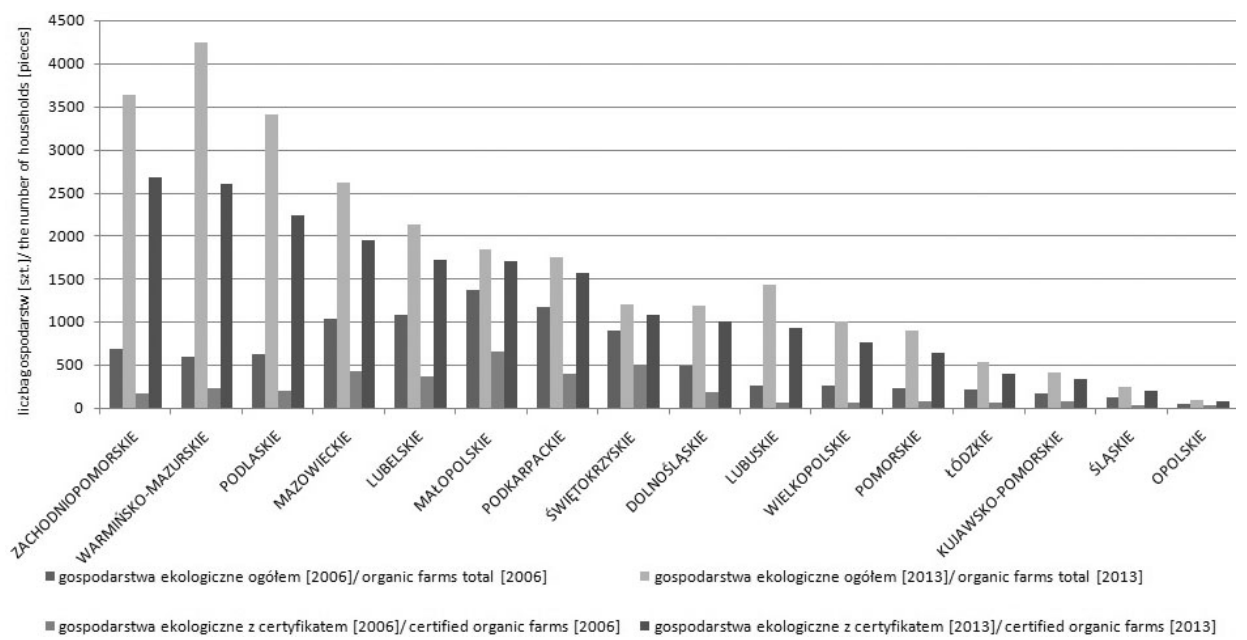

Ryc. 1. Liczba gospodarstw ekologicznych w Polsce w latach 2006-2013 wg województw Źródło: opracowanie własne na podstawie danych GUS.

Number of organic farms in Poland in years 2006-2013 by voivodships Source: own compilation based on Local Data Bank.

Te kierunki produkcji należą do pracochłonnych dziedzin wytwarzania i są mocno "zakotwiczone” w tradycyjnych kierunkach gospodarki rolnej. Z danych zamieszczonych w tabeli 1 wynika, że w sumie w województwie małopolskim nie działa dużo gospodarstw z certyfikatami ekologicznymi. Mają one jednak głównie charakter rodzinny, co w znacznym stopniu sprzyja ich trwałości oraz ciągłemu doskonaleniu sposobów gospodarowania. Szczególnego podkreślenia istniejącej odmienności rolnictwa ekologicznego Małopolski w stosunku do obszarów północnych i północno-wschodnich kraju wymaga też i ta cecha, że nierzadko gospodarstwa ekologiczne łączą swoją działalność z agroturystyką. W ten sposób znajdują zbyt na wytworzone produkty (żywienie gości, połączone najczęściej ze sprzedażą produktów), a ponadto uatrakcyjniają ofertę agroturystyczną.

\section{Gospodarstwa ekologiczne w przestrzeni Małopolski}

Interesującym problemem badawczym związanym z rolnictwem ekologicznym jest analiza jego aspektów dotyczących lokalizacji gospodarstw, a więc ich położenia w określonych warunkach geograficznych, położenia ekonomicznego związanego z cechami mikrorejonu, w którym funkcjonują oraz lokalizacji w stosunku do faktycznych i potencjalnych rynków zbytu. W Małopolsce występowanie gospodarstw ekologicznych cechuje wybitna nierównomierność i znaczne skoncentrowanie w kilku jego obszarach (ryc. 2). 


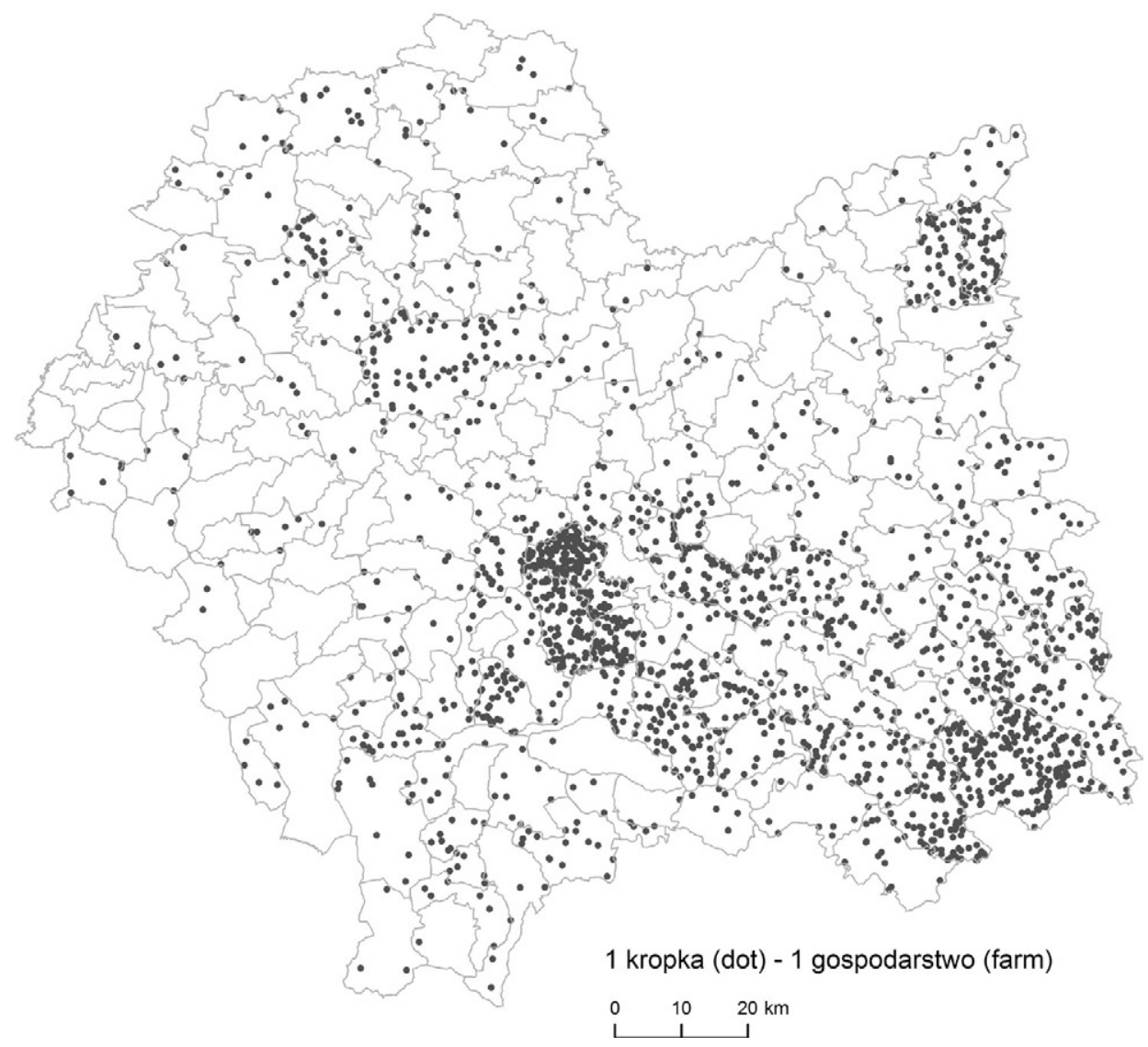

Ryc. 2. Gospodarstwa ekologiczne w województwie małopolskim w 2012 r.

Źródło: opracowanie własne na podstawie danych Inspekcji Jakości Handlowej Artykułów Rolno-Spożywczych. Organic farms in the Małopolskie Voivodship in 2012

Source: own compilation based on Agricultural and Food Quality Inspection data.

W regionie wyróżniają się dwa największe ich skupienia. Jedno z nich znajduje się w obrębie Beskidu Niskiego i częściowo Sądeckiego (ponad 400 gospodarstw, tj. prawie 1/5 ogółu), natomiast drugie obejmuje znaczną część Beskidu Wyspowego i jego otoczenia (powiaty limanowski i nowosądecki). Tutaj działalność prowadzi około 600 gospodarstw ekologicznych, czyli blisko 30\% wszystkich. Spora koncentracja omawianych gospodarstw jest też na północnym wschodzie Małopolski, w trójkącie pomiędzy Wisłą i województwem podkarpackim. Skupia ono około 150 gospodarstw (powiaty dąbrowski i tarnowski). W rozmieszczeniu działalności ekologicznej rolnictwa uwidacznia się też rola Krakowa, jako dużego rynku konsumenckiego, bowiem na jego terenie, a także w pobliżu miasta prowadzi działalność blisko 150 gospodarstw ekologicznych. W sumie na wymienionych obszarach znajduje się zdecydowana większość ekologicznych rolników - ponad 80\% ogółu, co można łączyć z głównymi czynnikami ich lokalizacji związanymi z warunkami przyrodniczymi, tradycjami gospodarowania w określonej dziedzinie rolnictwa oraz z możliwościami zbytu (Gil 2014). W ich obrębie znajdują się wszystkie gminy z najwiekszą 
liczbą gospodarstw ekologicznych, takie jak Uście Gorlickie (189 gospodarstw) Jodłownik (129) Dobra (86), Krynica Zdrój (71) czy Kraków (86), do których przylegają zwykle jednostki posiadające powyżej 30 gospodarstw.

Istniejąca koncentracja działalności ekologicznej w Małopolsce oraz występowanie rozległych obszarów pozbawionych gospodarstw ekologicznych dobrze oddaje rycina 2.

Tabela 1. Liczba i odsetek gmin w województwie małopolskim wg liczby gospodarstw ekologicznych

\begin{tabular}{|c|c|c|c|c|}
\hline \multicolumn{2}{|c|}{ Liczba } & \multirow[b]{2}{*}{$\%$ gmin } & \multirow{2}{*}{$\begin{array}{l}\text { Suma liczby } \\
\text { gospodarstw } \\
\text { ekologicznych }\end{array}$} & \multirow[b]{2}{*}{$\%$ gospodarstw } \\
\hline $\begin{array}{l}\text { gospodarstw } \\
\text { ekologicznych }\end{array}$ & gmin & & & \\
\hline Powyżej 100 & 2 & 1,2 & 318 & 16,7 \\
\hline 51-100 & 7 & 4,3 & 438 & 22,9 \\
\hline $31-50$ & 8 & 5,0 & 295 & 15,4 \\
\hline $16-30$ & 13 & 8,1 & 278 & 14,5 \\
\hline $2-15$ & 98 & 60,9 & 474 & 28,7 \\
\hline Poniżej 2 & 33 & 20,5 & 33 & 1,8 \\
\hline
\end{tabular}

Źródło: opracowanie własne na podstawie danych Inspekcji Jakości Handlowej Artykułów Rolno-Spożywczych.

Jak się okazuje, w ponad 80\% gmin województwa małopolskiego działalność ekologiczną prowadzi tylko po kilka, a rzadziej po kilkanaście gospodarstw, przy czym w 33 gminach (1/5 ogółu) istniało w 2012 r. tylko jedno gospodarstwo. O kilku powiatach województwa (chrzanowski, suski, oświęcimski, proszowicki) można powiedzieć, że idea ekologicznego gospodarowania nie znalazła tu w ogóle zainteresowania, zaś w dalszych 4 (brzeski, tatrzański wielicki, wadowicki), że jest realizowana w znikomym zakresie. Powiaty te mają po mniej niż 20 gospodarstw ekologicznych. Są to obszary różne pod względem struktury funkcjonalnej. W dwóch najbardziej rolniczych rejonach (powiat proszowicki i miechowski) liczba gospodarstw ekologicznych jest bardzo mała (mają one zarejestrowanych odpowiednio 8 i 20 takich jednostek). Tutaj producenci rolni, wykorzystując bardzo korzystne warunki środowiska rolniczego, prowadzą intensywną gospodarkę zbożową i chów trzody, oparty w dużym stopniu na przemysłowych metodach produkcji. Ponadto część rolników zamieszkujących wsie położone bliżej Krakowa uprawia sporo warzyw, których produkcja ma także intensywny charakter (Głębocki 2014). Pozostałe rejony z niskimi wskaźnikami rolnictwa ekologicznego mają znacznie zmienioną strukturę gospodarczą - dominuje gospodarka nierolnicza, a wśród gospodarstw przeważają bardzo małe powierzchniowo. Tutaj często ekologiczni producenci żywności łączą swoją działalność z agroturystyką.

Dla wyjaśnienia dużej koncentracji rolnictwa ekologicznego we wskazanych wcześniej obszarach Małopolski szczególnie istotne jest podkreślenie warunków naturalnych, które przyczyniły się do powstania w tych miejscach wyspecjalizowanego rolnictwa sadowniczego (Beskid Wyspowy) i hodowlanego (Beskid Niski i Beskid Sądecki - chów bydła mlecznego). W rejonach tych rolnicy dokonali konwersji metod prowadzenia produkcji, przestawiając je z intensywnych na ekologiczne, a jak wykazały badania własne autorki, motywacją do podjęcia takich decyzji były dopłaty do produkcji pochodzące z funduszy europejskich. Badani właściciele gospodarstw twierdzili, że o przestawieniu produkcji zadecydowała kalkulacja ekonomiczna, a inne czynniki nie miały istotnego znaczenia. Lokalizacja ekologicznych hodowców bydła w powiecie gorlickim wynikała z położenia terenów 
wypasowych w otulinie Magurskiego Parku Narodowego i w obszarach Natura 2000, gdzie wprowadzono różne ograniczenia dla intensywnej gospodarki na użytkach rolnych, w tym także łąkach i pastwiskach. Podobne uwarunkowania zdecydowały też o dużej liczbie ekologicznych gospodarstw sadowniczych w powiecie limanowskim i częściowo nowosądeckim. Jest to rejon o bardzo rozdrobnionym rolnictwie z gospodarstwami poniżej 3 ha powierzchni całkowitej, gdzie podjęcie ekologicznej produkcji mogło się wiązać z dążeniem do lepszego wykorzystania siły roboczej, a poprzez korzystanie z dopłat, mogło też zapewnić wyższe dochody (Hasiński i Grykień 2003).

\section{Główne problemy rozwoju rolnictwa ekologicznego w województwie małopolskim}

Z analizy stanu rolnictwa ekologicznego w województwie małopolskim wynika, że nie stanowi ono znaczącego segmentu regionalnej gospodarki żywnościowej. Zajmuje się nim niewielka liczba gospodarstw ( $0,7 \%$ ogółu), a areał na którym jest prowadzona działalność obejmuje tylko 2,7\% całości użytków rolnych regionu. Całkowita wartość ekologicznych produktów jest tu szacowana na około $18 \mathrm{ml}$ zł (0,5\% wartości produkcji rolniczej regionu). W dodatku w ostatnim okresie wskaźniki te spadają, bo część rolników rezygnuje z gospodarowania metodami ekologicznymi. Problemem jest też śladowa obecność rolnictwa ekologicznego na większości obszarów województwa, w tym szczególnie w rejonach o intensywnej gospodarce rolnej. Jak się wydaje, jedną z istotnych przyczyn tej sytuacji jest szeroko rozumiana polityka rolna i jej niedostosowanie do specyfiki regionu. Wynikiem tego jest obserwowane od dłuższego czasu zjawisko odchodzenia od produkcji rolniczej (w latach 2002-2010 dotyczyło to 24\% tutejszych gospodarstw). Badania własne pokazują, że w ostatnim czasie z produkcji ekologicznej rezygnują głównie drobne gospodarstwa. Jest ich najwięcej, bo stanowiły w 2012 r. ponad 48\% ogółu, a nieco większe - mające obszar od 5-10 ha - ponad 1/3. Rośnie natomiast grupa ekologicznych gospodarstw o powierzchni ponad 50 ha, które w dotychczasowym systemie dopłat korzystały najbardziej z funduszy przeznaczonych na rolniczą działalność ekologiczną.

Można oczekiwać, ze nowe zasady finansowania ekologicznych gospodarstw, przewidujące wyższe wsparcie dla małych gospodarstw i różnicujące dopłaty w zależności od rodzaju produkcji, poprawią warunki tworzenia ekologicznego rolnictwa w regionach silnie rozdrobnionych (Szymona 2013). Szczególnie ważne wydają się preferencje w nowym Programie Rozwoju Obszarów Wiejskich na lata 2014-2020 dla ekologicznej uprawy warzyw i ziół. Mogą one stać się atrakcyjne dla małych gospodarstw, bowiem do tej pory nie było wśród nich większego zainteresowania takim profilem produkcji. Kolejnym strategicznym sektorem mogą stać się „ekologiczne” owoce i warzywa - w 2012 r. wyprodukowano ich w regionie niewiele, bo tylko 228 ton, co stanowiło 4,6\% zbiorów ekologicznych krajowych. Tymczasem udział tego województwa w całkowitej produkcji warzyw Polski wynosił 11,1\%, a owoców 4,4\%.

Możliwe dla rolnictwa Małopolski jest też dalsze wzmocnienie ekologicznego sektora mlecznego. W 2012 r. tutejsi hodowcy dostarczyli na rynek ponad 112 hektolitrów mleka, co stanowiło prawie 1/3 krajowej produkcji ekologicznego mleka. Jest to o tyle interesujące, że Małopolska nie ma teraz dużego udziału w globalnym rynku polskiego mleka. Wyniósł on w 2012 r. zaledwie 3,1\%. Produkcja ekologiczna mleka pochodzi głównie z południa Małopolski, gdzie w kilku gminach chów bydła prowadzi kilkaset gospodarstw, 
wykorzystując naturalne pastwiska porastające niskiej klasy grunty rolnicze. W takich gminach jak: Uście Gorlickie, Krynica Górska, Łabowa, Sękowa oraz w gminach podhalańskich, większość gruntów znajduje się w V i VI klasie bonitacyjnej, a istniejąca tu jeszcze w latach 70. i 80. uprawa zbóż i ziemniaków zanikła zupełnie (Górz 2004). Rolnicy ze wspomnianych gmin i innych obszarów o niekorzystnych warunkach przyrodniczych (ONW) są beneficjentami znacznych środków pomocowych z Unii Europejskiej, co dodatkowo motywuje ich działania o charakterze ekologicznym. W 2012 r. w całym regionie Małopolski wypłacono z tytułu dopłat do ONW (był to obszar 114 tys. ha, tj. 7,5\% powierzchni województwa) prawie $50 \mathrm{mln}$ zł rozdzielonych pomiędzy 30,5 tys. gospodarstw. Trudno stwierdzić, czy ta wysoka pozycja Małopolski w produkcji mleka sposobami ekologicznymi utrzyma się. Doradcy rolników ekologicznych z gminy Uście Gorlickie obserwują stagnację zainteresowań chowem ekologicznym bydła mlecznego, a w kilku przypadkach odnotowano nawet rezygnację z tej metody produkcji. Powodem rezygnacji jest za niska cena skupu, w stosunku do innych producentów. Rolnicy uważają też, że na zaniżenie ceny wpływa odległy transport. Wytworzone mleko jest transportowane do dosyć odległych miejsc do mleczarni w Nowym Sączu i w Nowym Targu. Twierdzą, że ich sytuację dochodową mogłoby poprawić lokalne przetwórstwo mleka w zakładzie działającym w pobliżu producentów, którzy mogliby być współudziałowcami. Jest to jednak, jak się wydaje problem całego sektora polskiej produkcji ekologicznej. Jego bardzo słabą stroną jest przetwórstwo. Większość produktów ekologicznych Polska eksportuje do krajów zachodnich, skąd z kolei sprowadzane są przetworzone i gotowe do spożycia przetwory (Szymona 2013). W 2012 r. w całym kraju działało 213 przetwórni ekologicznych, z czego aż 46\% w województwie mazowieckim, wielkopolskim i lubelskim. W Małopolsce były 24 przetwórnie, ale aż 16 zajmowało się importem produktów ekologicznych i ich dostosowywaniem na polski rynek.

Aby te problemy rozwiązać, musi w naszym kraju powstać spójny rynek produkcji ekologicznej. Obecnie jest on rozdrobniony i niepowiązany wewnętrznie, a słabymi ogniwami są właściwie wszystkie jego segmenty, tj. gospodarstwa ekologiczne, ogniwa skupu i przetwórstwa, a także dystrybucja i promocja żywności ekologicznej. Wiele musi się zmienić w samej polityce rolnej, zwłaszcza w jej segmencie dotyczącym ekologicznego rolnictwa.

\section{Wyniki badań własnych}

Spośród przebadanych 100 gospodarstw najliczniejszą grupę (37\%) stanowiły te prowadzone od 3 do 5 lat oraz gospodarstwa, które produkują metodami ekologicznymi ponad 5 lat - 30\%. W sumie te dwie grupy skupiają prawie 70\% ankietowanych gospodarstw (ryc. 3). Ich średnia powierzchnia wyniosła 15 ha, natomiast wiek 64\% ankietowanych zawierał się w przedziale 35-45 lat. Ponad połowa ankietowanych prowadzących gospodarstwo ekologiczne posiada wykształcenie wyższe (57\%). Jak więc widać, jest to domena ludzi młodych, dobrze wykształconych, którzy w odpowiedni sposób wykorzystują szanse w postaci wielu możliwości dofinansowań. Każdy z respondentów korzystał ze wsparcia poprzez dopłaty bezpośrednie do użytków rolnych oraz z PROW z pakietu rolnictwo ekologiczne w ramach Wspólnej Polityki Rolnej. Ponadto część z nich (12\%) korzystało ze wsparcia przeznaczonego dla Obszarów o Niekorzystnych Warunkach gospodarowania (ONW). 


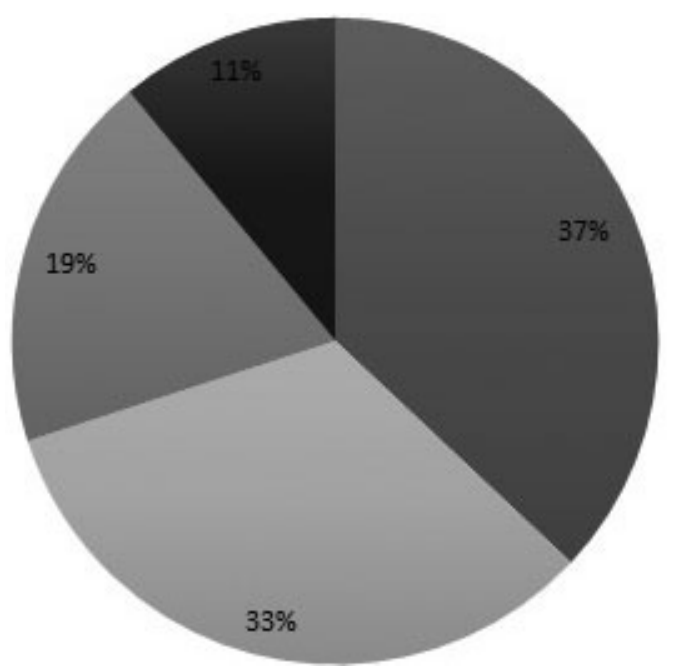

a-5lat/ $3-5$ years

E powyżej 5 lat/ over than 5 years

-1-3lata/ $1-3$ yeras

Eniespełna $1 \mathrm{rok} /$ less than 1 year

Ryc. 3. Okres prowadzenia gospodarstwa ekologicznego

Źródło: na podstawie badań własnych.

Period of running an organic farm

Source: own elaboration.

Ciekawym jest fakt, że produkcja roślinna prowadzona była w każdym z analizowanych gospodarstw. Profil działalności najczęściej był wielokierunkowy (63\% odpowiedzi; ryc. 4)

- łączyły one produkcję warzyw, owoców, a także zbóż i chów zwierząt.

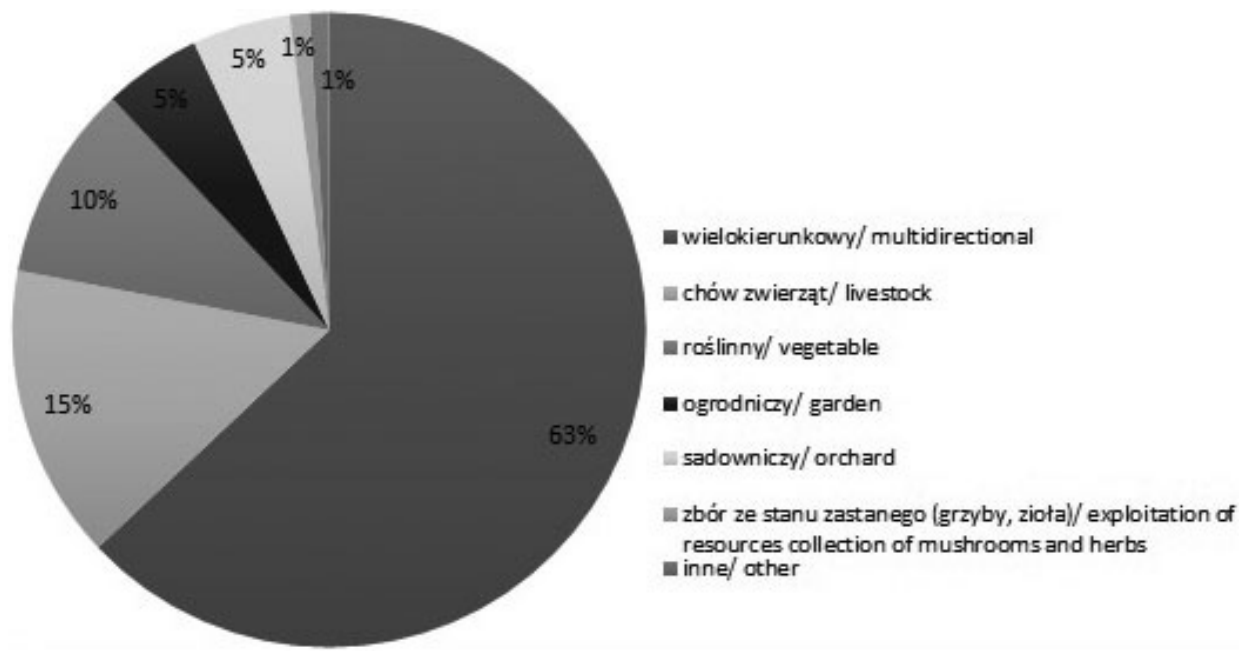

Ryc. 4. Profil produkcji analizowanych gospodarstw ekologicznych

Źródło: na podstawie badań własnych.

Production profile of analyzed organic farms

Source: own elaboration. 
Produkty, które w opinii respondentów najłatwiej można sprzedać to: owoce (53\%), mleko oraz przetwory mleczne (45\%), warzywa (39\%). Najczęściej wytworzoną żywność badani rolnicy sprzedają bezpośrednio z gospodarstwa oraz na targowiskach (2/3 respondentów), połowa z nich dostarcza swoje produkty do specjalistycznych sklepów. Dotyczyło to głównie gospodarstw zlokalizowanych w pobliżu chłonnego rynku zbytu - Krakowa.

Na podstawie przeprowadzonych badań ankietowych oraz rozmów z rolnikami można stwierdzić, że istnieje wiele ograniczeń rozwoju rolnictwa ekologicznego. Głównym jest brak dostatecznej opieki instytucjonalnej po konwersji gospodarstwa z tradycyjnego na ekologiczne. Ponad połowa (54\%) respondentów uważała, że spełnianie rygorystycznych wymogów i bezpośrednio z tym związana biurokracja oraz częste kontrole wpływają negatywnie na rozwój tego sektora rolnictwa.

Część ankietowanych rolników wskazuje, że nie ma spójnego systemu funkcjonowania tych gospodarstw w gospodarce żywnościowej. Dobrze zorganizowany jest ich zdaniem sam proces tworzenia gospodarstw ekologicznych. Także ich funkcjonowanie jest określone i sformalizowane. Natomiast zupełnie niezorganizowany jest proces dystrybucji produktów ekologicznych. Nie ma odpowiedniej reklamy, na co wskazywał co trzeci badany, a co najważniejsze nie funkcjonuje sieć dystrybucji, na co zwróciła uwagę większość ankietowanych (76\%). Konsekwencjami wszystkich barier, które pojawiają się w toku prowadzenia gospodarstw ekologicznych, jest chęć rezygnacji części rolników z prowadzenia gospodarstwa metodami ekologicznymi, na co wskazała aż 1/3 badanych. Niższe plony, skomplikowane procedury certyfikacji, kontrole, zmiany w finansowaniu działań proekologicznych prowadzą coraz częściej do rezygnacji rolników z prowadzenia gospodarstw ekologicznych, gdyż często bilans zysków i strat jest niestety na niekorzyść rolników.

\section{Podsumowanie}

Z przedstawionych analiz wynika, że rolnictwo ekologiczne, traktowane w tej pracy jako przejaw innowacyjnych działań w sektorze rolnym Małopolski, ma w tym regionie niewielkie znaczenie. Idea wytwarzania zdrowej żywności nie znalazła tu jak dotąd szerszej akceptacji, zwłaszcza na obszarach o istotnym znaczeniu funkcji rolniczej (północna część Małopolski). W podejmowaniu decyzji o przestawianiu produkcji na ekologiczne sposoby wytwarzania najistotniejsze okazały się dopłaty i kalkulacje opłacalności takiej działalności. Dlatego rolnicy gospodarujący na obszarach o wysokich wskaźnikach jakości rolniczej przestrzeni produkcyjnej nie zmieniali metod gospodarowania, natomiast robili to znacznie częściej rolnicy mieszkający na terenach górskich, gdzie korzyści z ekologicznego rolnictwa okazały się największe. W rozwiązywaniu problemów rolnictwa ekologicznego Małopolski i wzroście znaczenia w regionalnej gospodarce żywnościowej trzeba uwzględniać różne czynniki i uwarunkowania jego funkcjonowania, zarówno wynikające z trendów europejskich rolnictwa, jak i sytuacji krajowej oraz specyfiki lokalnej obszarów wiejskich. W państwach Europy Zachodniej rośnie zainteresowanie „zdrową żywnością” i rosną też wydatki związane z jej zakupem. W bogatej Szwajcarii wynoszą one średnio w roku około 180 euro na 1 mieszkańca, gdy w Polsce jedynie 3 euro. Niemniej w dalszym ciągu jest to niszowa część całej produkcji rolniczej Europy, którą można łatwo „zagospodarować”. Rolnictwo ekologiczne, jako użytkownik przestrzeni Małopolski, może najlepiej zrealizować cele ochrony przyrody tej części kraju, w której biorą początek liczne dopływy Wisły 
i gdzie znajdują się największe powierzchnie obszarów chronionych. Równocześnie może to być istotny czynnik zmian w tutejszym rolnictwie, które z przyczyn historycznych i braku współczesnych reform, pozostaje nadal silnie rozdrobnione i jest coraz bardziej marginalizowane jako producent żywności. Przechodzenie na ekologiczne sposoby gospodarowania może też być ważnym składnikiem modernizacji gospodarstw regionu zarówno w wymiarze ekonomicznym, jak i technologicznym oraz organizacyjnym. Sposoby te wymagają bowiem sporej wiedzy zdobywanej przez rolników na szkoleniach, ciągłego dokształcania i korzystania z pomocy nauki.Rolnicy potrzebują szerokich kontaktów z otoczeniem rolnictwa i jego instytucjami, a także współdziałania z innymi producentami, co wydaje się szczególnie ważne wobec zakorzenionej tu niechęci do łączenia się w grupy czy zespoły producentów. Szansą dla części gospodarstw ekologicznych jest też agroturystyka, mająca tu dobre warunki rozwoju.

\section{Literatura}

Gil A., 2014, Współczesne funkcje rolnictwa Małopolski, [w:] R. Rudnicki, M. Kluba (red.), Zintegrowany rozwój obszarów wiejskich w świetle polityki Unii Europejskiej, 1, Rolnictwo i Wspólna Polityka Rolna, Wydawnictwo Naukowe Uniwersytetu Mikołaja Kopernika, Toruń, s. 149-170

Głębocki B. (red), 2014, Zróżnicowanie przestrzenne rolnictwa. Powszechny Spis Rolny 2010, Główny Urząd Statystyczny, Warszawa.

Górz B., 2004, Współczesne przemiany na obszarach wiejskich południowo-wschodniej Polski, Studia Obszarów Wiejskich, 6, s. 197-218.

Guzik C., Leśnicki J., 2003, Development of rural settlement in Podhale, Prace Geograficzne 112, IGiGP UJ, Kraków.

Hasiński W., Grykień S., 2003, Bariery rozwoju rolnictwa ekologicznego na Dolnym Ślq̨sku, [w:] B. Górz, Cz. Guzik (red), Współczesne przekształcenia i przyszłość polskiej wsi, PTG, Uniwersytet Jagielloński, Kraków, s. 111-122.

Szymona J., 2013, Szanse i zagrożenia polskiego rolnictwa ekologicznego w perspektywie lat 20142020, Kancelaria Senatu, Warszawa.

Zegar J. St., 2008, Gospodarstwa ekologiczne w rolnictwie indywidualnym, Wiadomości Statystyczne, 8, s. 49-61

\section{Summary}

The Małopolskie Voivodship is characterized by a very low concentration of agriculture, with slowly transforming structure and modernization of production methods. A large part of the smallest farms resign from conducting farming activity and managing animal husbandries. This leads to decreased effectiveness of the agricultural sector in the region and limits facilitation of the existing labor force, the resources of agricultural land and the capital involved in this sector. Nevertheless, innovative activities are undertaken in this region consisting in development of multifunctional agriculture and organizing ecological or agritourism farms or farms which manufacture agricultural products with traditional methods (regional products). In this thesis, the author has focused on organization and operation of ecological farms which amount to nearly 2 thousand in the Małopolskie Vo- 
ivodship. They constitute $9 \%$ of ecological farms in the entire country. Their existence and fast development may be treated as a significant direction of agricultural transformations in the national scale. The paper includes an analysis of the quantitative dynamics of such farms, as well as a characteristics of preconditions for their development in various conditions, both in terms of natural environment and socio-economic aspects. Furthermore, the main issues related to production, sales and processing have been described. The author has also made an effort to present their perspective as one of the methods of revitalizing agriculture in the region. To a large extent, the thesis is based on the author's own research conducted at the ecological farms operating in the Małopolskie Voiviodship. 